\title{
Empirical Research on Leadership Capacity of Secondary Vocational Teachers in Yunnan Province of China
}

\author{
Xiaoyao Yue ${ }^{1} \&$ Yongjun Feng ${ }^{2}$ \\ ${ }^{1}$ Higher Education Research Institute, Yunnan University, Kunming, Yunnan, China \\ ${ }^{2}$ School of Education, Shaanxi Normal University, Xi'an, Shaanxi, China \\ Correspondence: Yongjun Feng, School of Education, Shaanxi Normal University, Xi'an, Shaanxi, China. \\ E-mail: fengyongjun_cn@126.com
}

Received: November 10, 2020 Accepted: December 12, 2020 Online Published: December 16, 2020

doi:10.5539/jel.v10n1p7 URL: https://doi.org/10.5539/jel.v10n1p7

\begin{abstract}
Teacher leadership continues to be a growing educational reform initiative across the world. With the rapid development of Chinese language education, the role of teacher leadership in education reform is becoming more and more prominent. Based on the survey data of 104 teachers in a secondary vocational school in Yuxi City, this study investigated the level of teacher leadership capacity and discussed their promotion strategies. Based on Lambert's (2003a) theory of teacher leadership capacity, the author developed a research questionnaire that including four structures of teacher leadership capacity, which focus on the vision, reflection and innovation, shared governance, supervision, and response to student achievement. This study adopted the five-likert point scale. Data analysis shows that the average scores of 17 items does not exceed 4.00 points, while the highest and lowest score are from "focus on the vision." To improve the teacher leadership capacity, the study suggests that leaders should concentrate on the school's vision as well as establish collaborative culture and atmosphere among teachers.
\end{abstract}

Keywords: teacher leadership, vocational school, Yuxi city

\section{Introduction}

Teacher leadership can be difinited as learning together to achieve a common vision. Teacher leadership is the extensive work on behalf of management, the establishment of a learning team and getting along with other stakeholders (Lambert, 2003a). According to Jiandong (2018), since the 1980s, teacher leadership has attracted many scholars, educators, and administrators in the field of education reform in the United States. China has been concentrating on teacher leadership for ten years. As an emerging discipline, teacher leadership mainly refers to enhancing teaching ability and development ability. Through sharing power among teachers, leaders evoke and enhance teachers' self-recognition of leadership. Teacher leadership is a vital component that can inspire teachers' potential talents, academic skills, respect for teaching and research, career sharing and professional development (Jiandong, 2018). Regarding the combination of teacher leadership with practice, the head teacher in class plays a vital role in the development of teacher leadership. Most researches have focused on teacher leadership in K-12 education. In vocational education section, the number of documents is limited. Dan (2014) summarized four dimensions that influence teacher leadership: self-awareness, professional leadership, skills of leadership collaboration, and participation in school affairs. Individuals and institutions lack a sense of understanding teacher leadership, because people are influenced by traditional values and stereotypes, while schools do not have incentives and sound democratic systems. Therefore, few people paid attention to teacher leadership in China. More specifically, no research on teacher leadership has been conducted in Yunnan Province, a rapid growing region in Western China. Yuxi is the second-largest economic city in Yunnan Province and ranks 11th among the 50 western cities in China $(\mathrm{Li}, 2014)$. This research was carried out in a secondary vocational school in Yuxi. The purpose of this article is to discuss the status of teacher leadership in this secondary vocational school. Correspondingly, teachers' knowledge of leadership was reflected in this investigation. As a result, school leaders and administrators may more clearly learn the teachers' leadership abilities through this work. 


\subsection{Research Objectives}

1) To identify the current level of teacher leadership in the secondary vocational school in Yuxi.

2) To explore the strategies which could enhance teacher leadership in the secondary vocational school.

\section{Literature Review}

\subsection{Context of the Study}

In the past few decades, the number of available teacher leaders has increased immeasurably, yet building teacher leadership is still a troublesome issue. Teachers demand leadership and give students a sense of learning (Dan, 2014). Dan (2014) found it is necessary to give teachers self-recognition of leadership skills. He concluded that teacher leadership should include stimulating teachers' potential talents, strengthening teachers' professional academic leadership, respecting teachers' leadership in teaching and research, sharing profession and career development, reshaping organizational culture, and enhancing collaboration and establishing a school learning environment. Ming (2008) suggested that the principal should be responsible for everything that happens on the campus. However, it is dangerous for the principals have rights and have everything. In this regard, teacher leadership can solve this problem. Teacher leadership is hope to incorporate it into school leadership. Teacher leadership is beneficial to the improvement of administrative management, teacher career, student learning, lifestyle and school development (Ming, 2008).

In China, the development of secondary vocational education is still in its infancy, and its purpose is to train high-quality graduates with knowledge and skills. The schooling period is three years (Lichan \& Xiaoyun, 2018). Zhijing (2016) pointed out that there are nearly 10,000 secondary vocational schools with about 1.8 million students in China. As an example, the selected secondary vocational school in this study has 3842 students and 310 teachers and teaching staff. From the official website of this school, visiters can find that the school adheres to a people-oriented and ability-based vision, to provide educated and skilled students to society. The author had worked in this school before and noticed that teachers did not have enough decision-making opportunities and were not empowered. Furthermore, the teachers were not very active in improving students' grades. There was limited innovation and creativity in learning methods and classroom teaching strategies. Therefore, this study was conducted to determine the current level of teacher leadership capacity in this secondary vocational school.

\subsection{Understanding Teacher Leadership Capacity}

Since the 1980s, under the constraints of increasing student outcomes and authoritarian policies, teacher leadership has become an important focus of educational reform (Smylie \& Eckert, 2018; Mangin, 2007). More and more researches require advocates of teacher leadership to appoint positions and undertake school management tasks in stead of teaching in classroom. The principal must distribute his power among others and must cooperate with many stakeholders. Given this, distributed leadership is behooving. Smylie and Eckert (2017) recorded that encouraging teachers to participate in the decision-making process and school improvement is as if teachers have been given leadership skills. To date, only limited research has examined teacher leadership capacity. Ultimately, the goal of school leadership is to promote student success and school progress. Although teacher leadership is not a new concept and it has been studied in various literature, its importance needs to be strengthened to adapt to the current school development strategies. The principal may learn more about teachers' leadership and use their contributions to further improve the school management. As a result, teachers can participate in school affairs and show better performance in management positions (York-Barr \& Duke, 2010).

Leadership affects people's behavior, motivations, and actions for achieving organizational success (Bush, 2007; Marion \& Gonzales, 2014). Teachers seek to demonstrate performance beyond traditional roles and often exhibit informal leadership skills by showing their expertise, presenting ideas and participating in new projects (Brundreet, 2003). Through leadership training, teachers can become leaders (English et al., 2012). Emira (2010) concluded that the teacher leadership style is achieved by combining the roles of formal and informal leadership. Senior teachers and executive-level teachers are job leaders who inspire peers, come up with new suggestions and ideas, and share experiences. They exercise formal leadership responsibilities, they are supervisors, coaches, set missions and visions for classrooms, lead and collaborate with colleagues, guide novices and attend school meetings. Two types of teacher leadership constitute the work of teachers' leader. Many researchers have found that the purpose of leadership practice is to "balance and improve the opportunities" (p. 7) and prospects of school improvement. Teachers most conveniently collect data on student performance and school culture (Emira, 2010).

As Wenner and Campbell (2017) pointed out, teacher leadership is more attractive as one of the important school leaderships since it embraces student learning. Teacher leadership practises in classroom every day as part of 
daily life. Furthermore, teachers cooperate with their peers. They can learn from each other and deal with problems together. Teachers use their experience to improve and transform schools. In turn, leaders adopt strategies to promote teacher cooperation and help them to explore the best practices for professional development (Wenner \& Campbell, 2017). Teacher leadership has two core functions: one is to contribute to school improvement, and the other is to achieve organizational goals. Silva and Gimbert (2000) found that teacher leadership can enable students to participate more actively in learning activities. However, teacher leadership is a challenge in the traditional school system. Teachers rarely participate in leadership activities, such as school design, peer guidance, decision-making processes, school-level attendance and teacher professional development.

Teacher leadership refers to teaching and curriculum leadership. Teachers focus on what is exciting and necessary and explore opportunities to improve the school outside of classrooms. Against this background of teacher leadership, teachers have invested in the future for the school. Teacher leadership is not only about passion and responsibility, but also closely related to school reform (Grant, 2017). By combining teacher leadership and practice, some research has been conducted on K-12 education, but less attention has been paid to higher education and vocational education (Jiandong, 2018). After understanding the importance of teacher participation in improving schools, decision makers need to provide teachers with leadership capacity (Hamilton, Forde, \& McMahon, 2018).

In addition, the concept of teacher leadership capacity is currently related to various meanings in the curriculum and teaching era. The attributes of vocational teaching include: (1) setting a clear goal and selecting the most useful course content; (2) assuming the characteristics and learning methods of students; (3) providing learning planning services; (4) designing the learning activity models and requirements (Li, Hau, Huang, \& Huang, 2011; Shiudong, 2011). In vocational education, the development of school vision is reflected in capable teachers (Hodkinson, 1998). In the absence of sufficient industry experience, vocational teachers were given basic academic education. They are more theoretical and textbook; they need teaching theory and workplace knowledge. Therefore, they can supervise, teach and train students (Bakar, 2018; Attuell, 1997).

\subsection{Teacher Development in Secondary Vocational Education}

In vocational schools, student learning is the most important matters. Students need professional experiences and skills to apply in practice. The general vocational course has the following characteristics: (1) requires more technical skills than academic knowledge; (2) allows learners to focus on specific training for the profession; (3) supports flexible programs with multiple sources (Mouzakitis, 2010; Bruijn \& Leeman, 2011). In vocational schools, course is designed to help students find their way of life and develop their ability to face transition and adaptation in the workplace. Vocational training enables students to learn knowledge, skills and professional identity (Martins, 2015; Billett, 2011).

Secondary vocational schools are expected to promote services and students' knowledge in the learning process (Drummer et al., 2018). In 2006, a study of the OECD International Student Assessment Program emphasized the importance of lifelong learning for professional teachers. The program provides professional teachers with work-based guidance, especially to update knowledge during their training. Usually, professional training for vocational teachers is conducted in universities, and their coaches are university lecturers (Bunning et al., 2006; Constant et al., 2014). Regarding reflection and innovation, teachers are encouraged to give feedback on the content. Vocational teachers should play an essential role in maintaining teaching changes. It is common for some institutions to create training programs for teachers outside of their design (Vähäsantanen, 2013; Anderson, Barrick, \& Hughes, 1992). Technical and vocational education training focus on the teaching of teacher abilities (Grollmann, 2008). The vocational education and training (VET) system for Teachers Professional Development (TPD) includes knowledge, actions, motivations and problem-solving skills (OECD, 2011; Oser, Salzmann, \& Heinzer, 2009). In vocational schools, TPD is related to competency-based education, which requires teachers to change their role from experts to students (Seezink, 2009).

\subsection{Lambert's Theory of Teacher Leadership Capacity}

Lambert (2003a) described leadership as learning together to achieve a common vision, which truly combines learning and leadership. Teachers must learn together, and everyone has their ownership spirit. Leadership is a purposeful learning tool in the community. It encourages teachers to cooperate with colleagues and students by asking questions, constructing knowledge, evaluating and reflecting teaching. Teacher leadership is related to the extensive work on behalf of management, the establishment of a learning team and getting along with other stakeholders. Teachers seek performance beyond traditional roles and informal leadership, such as making plans, teaching and learning with peers, appropriately challenging values and beliefs, dealing with conflicts and 
problems between groups, designing active learning for students, and using problems to make decisions.

Lambert (2003a) took advantage of teacher leadership capacity, which included a strong focus on ideas, reflection and innovation, shared governance, supervision, and responses to student achievement. Using this theory as a research questionnaire, this study will determine the current level of teacher leadership capacity of a Yuxi secondary vocational school. The questionnaire contains four parts:

\subsubsection{Intense Focus on the Vision}

Intense focus on the vision refers to teachers who share a common vision in the organization. The principal's vision is the commitment of the participants. A shared vision is the common goal of the learning community, as well as teachers, leaders, and students work together to achieve the goal. Teacher cooperation in teaching and learning is very significant. According to the vision of the educational environment, teachers can connect their ideas with standards, guidance and evaluation. Teachers mainly focus on school vision, teaching and learning improvement, professional learning communities and student learning. This section has been revised based on the Leadership Capacity Survey. Since student learning is the most important task of the school, the author added the item "focus on student learning". Teachers may often observe and collect data to improve the school. In addition, the "Use Data/Evidence to Guide Our Decisions and Teaching Practices" project was added.

Table 1. Construct 1 of questionnaire

\begin{tabular}{|c|c|}
\hline Shared vision results in program coherence (Lambert, 2003a) & $\begin{array}{l}\text { Construct 1: Intense focus on the vision. In our school, } \\
\text { we... }\end{array}$ \\
\hline $\begin{array}{l}\text { 1. Participates with others in the development of a shared vision } \\
\text { and insists upon a vision that serves all children well. }\end{array}$ & 1. develop school vision together \\
\hline 2. Asks questions that keep the school on track with its vision. & $\begin{array}{l}\text { 2. ... ask everyone questions that keep us on track with our } \\
\text { vision }\end{array}$ \\
\hline \multirow{4}{*}{$\begin{array}{l}\text { 3. Thinks about and aligns school standards, instruction, } \\
\text { assessment, and programs according to the school's vision. } \\
\text { 4. Suggests that the school keep its vision alive by reviewing it } \\
\text { regularly. }\end{array}$} & $\begin{array}{l}\text { 3....think jointly about how to align our standards, } \\
\text { instruction, assessment, And programs with our vision }\end{array}$ \\
\hline & 4. ...keep our vision alive by reviewing it regularly \\
\hline & 5. ... focus on student learning \\
\hline & $\begin{array}{l}\text { 6. ...use data/evidence to inform our decisions and teaching } \\
\text { practices }\end{array}$ \\
\hline
\end{tabular}

\subsubsection{Reflection and Innovation}

Regarding reflection and innovation, teachers are encouraged to provide feedback with peers and students. Numerous teachers' reflective practices about the courses they teach, such as peer coaching, diary writing, and collaborative planning, are daily performed. Since teachers are teaching experts, they must explore new teaching strategies. Therefore, policymakers often encourage teachers to ask questions, meanwhile they should also pay attention to potential issues, such as teachers' access to resources, investment in updating methods and actions, as well as personal and shared work responsibility standards (Lambert, 2003a). Teachers are very sensitive to what they learn, they can learn from student feedback, peer discussion or tutoring, and innovate teaching paradigms that adapt to high-speed society. In Construct 2, in order to reflect and innovate, teachers can "join with other schools and planned networks inside and outside the area to ensure feedback on our work."

Table 2. Construct 2 of questionnaire

\begin{tabular}{|c|c|}
\hline $\begin{array}{l}\text { Reflective practice consistently leads to innovation (Lambert, } \\
\text { 2003a) }\end{array}$ & Construct 2: reflection and innovation. In our school, we... \\
\hline 1. Encourages reflection among colleagues and students. & $\begin{array}{l}\text {...make time for ongoing reflection (e.g., journaling, peer } \\
\text { aching, collaborative planning) }\end{array}$ \\
\hline $\begin{array}{l}\text { 2. Uses reflective practices such as peer coaching, journal writing, } \\
\text { collaborative planning. }\end{array}$ & $\begin{array}{l}\text { 2. ...encourage individual and group initiative by providing access } \\
\text { to resources, personnel, and time. }\end{array}$ \\
\hline $\begin{array}{l}\text { 3. Demonstrates and encourages initiative (e.g., posing questions, } \\
\text { accessing resources, joining networks). }\end{array}$ & $\begin{array}{l}\text { 3....have joined with networks of other schools and programs, both } \\
\text { inside and outside the district, to secure feedback on our work. }\end{array}$ \\
\hline 4. Invites and supports new ways of doing things. & 4. ...practice and support new ways of doing things \\
\hline $\begin{array}{l}\text { 5. Works with others to develop accountability criteria and processes } \\
\text { for our school. }\end{array}$ & $\begin{array}{l}5 . \ldots \text { develop our own criteria for accountability regarding individual } \\
\text { and shared work }\end{array}$ \\
\hline
\end{tabular}




\subsubsection{Shared Governance}

Teachers can share that governance and vision, which are key elements of school success because this is conducive to students' academic performance and achievements (Lambert, 2003a). Teachers establish representative governance groups, seek performance beyond traditional roles, and establish new ways for teamwork. With the empowerment of teachers to become the core of teacher leadership, teachers expect to assume important positions at the management level. In this investigation, the author adopted "shared governance in our school" instead of "Broad-based participation in the leadership". These projects are more precise, shorter, and more suitable for teacher leadership. Teachers seek to demonstrate performance beyond traditional roles and often demonstrateperform informal leadership skills by showing their expertise, presenting ideas and participating in new projects (Brundreet, 2003).

Table 3. Construct 3 of questionnaire

\begin{tabular}{ll}
\hline $\begin{array}{l}\text { Broad-based participation in the work of leadership (principals, teachers, students, } \\
\text { parents, community members) (Lambert, 2003a) }\end{array}$ & Construct 3: Shared governance. In our school, \\
\hline $\begin{array}{l}\text { we... Assists in the establishment of representative governance and work groups (e.g., } \\
\text { teams, councils, study groups) }\end{array}$ & $\begin{array}{l}\text { 1....have established representative governance } \\
\text { groups }\end{array}$ \\
$\begin{array}{l}\text { 2. Seeks to increase interactions among staff, students, and community members in } \\
\text { order to build relationships and increase participation. }\end{array}$ & $2 . .$. seek to perform outside of traditional roles \\
3. Shares authority and resources broadly. Engages others in leading opportunities & 3....have developed new ways to work together \\
\hline
\end{tabular}

\subsubsection{Monitors and Responses to Student Achievement}

Teachers are supervisors and promoters of student performance. The scope of student achievement beyond grades includes student development, performance, values, skills and a sense of presence and maturity. In the daily classroom investigations, teacher assesses the student's learning situation, and then provides the student's learning progress and performance to the family. Teachers leadership capacity can continuously stimulate school development through activities, develop school culture, promote innovation in teaching and learning, coordinate curriculum and improve students' academic performance.

Table 4. Construct 4 of questionnaire

\begin{tabular}{|c|c|}
\hline $\begin{array}{l}\text { High or steadily improving student achievement and } \\
\text { development (Lambert, 2003a) }\end{array}$ & $\begin{array}{l}\text { Construct 4: Monitors and responses to student achievement. } \\
\text { In our school, we... }\end{array}$ \\
\hline 1. Teaches and assesses so that all children learn. & 1....teach and assess so that all children learn \\
\hline Provides feedback to children and families about student progress. & \\
\hline 2. Talks with families about learning expectations and performance & 2. ...provide feedback to children and families about student progress \\
\hline $\begin{array}{l}\text { 3. Makes sure that school inquiry process includes evidence of } \\
\text { student performance and development. }\end{array}$ & $\begin{array}{l}\text { 3. ...talk with families about student performance and school } \\
\text { programs }\end{array}$ \\
\hline
\end{tabular}

\section{Methodology}

\subsection{Ethics Statement}

The study was conducted at a secondary vocational school, Yuxi of Yunnan Province, China. Prior to the start of the study, this particular study was reviewed and approved by the institutional review board (ethics committee) of this school. The leader helped the author to send the questionnaire to the teachers, and then the author collected the data within two weeks. The person in charge is not allowed to display the name of the institution.

\subsection{Research Design}

This study uses a descriptive design. The questionnaire consists of two parts. Part 1 interviews the demographic data of teachers in the Yuxi secondary vocational school. Part 2 evaluates the teacher leadership capacity of the Yuxi secondary vocational school. Descriptive statistics determines the demographic profile and current level of leadership capacity of teachers in this secondary vocational school in Yuxi.

\subsection{Sample and Population}

According to the research of Krejcie and Morgan (1970), the sample size Abbreviation Table of Sample Sizes (S) required for the population size $(\mathrm{N})$ is selected. This Yuxi secondary vocational school has five departments, namely business, language, medicine, computer, art and electronics. The author adopted convinent sampling 
collection methods. There are 172 full-time teachers in this secondary vocational school, while 104 teachers responded the online suevry, thus the reply rate was $60.5 \%$.

\subsection{Research Instrument}

The author developed a new questionnaire based on the Leadership Capacity Staff Survey (Lambert, 2003a, pp. 106-109). This study used a questionnaire to determine the level of leadership capacity of teachers in this secondary vocational school. The tool was developed based on the Lambert Teacher Leadership Theory (2003a) and the Cronbach questionnaire is 0.920 and includes 22 items. This questionnaire adopted five likert scale, participates chose 1-5 according their situation (see the Appendix A).

\subsection{Definition of Terms}

\section{Teacher leadership capacity}

Teacher leadership capacity includes the four teacher leadership structures used in the research questionnaire, such as high focus on vision, reflection and innovation, shared governance, supervision, and response to student achievement.

\section{Intense focus on the vision}

This sentence is a prospect, the wishes of the secondary vocational school, teachers and the ideal goal of the future. (This topic is covered in survey $1-6$ of Part II of the questionnaire)

\section{Reflection and Innovation}

This part is teachers' action, corporation when they are involved in the secondary vocational school. (This topic covered in question 7-11 in Part II of the questionnaire)

\section{Shared Governance}

It refers to collaboration, position, authority in this secondary vocational school when the teachers are involved. (This topic is covered in question 12-14 in Part II of the questionnaire)

\section{Monitors and responses to Student Achievement}

It means teacher performances and student achievements the Yuxi secondary vocational school when they are involved. (This topic is covered in question 15-17 in Part II of the questionnaire)

\section{A Yuxi secondary vocational school}

The selected secondary vocational school has 3842 students, 310 teachers, and teaching staff. The school insists on people-oriented and ability-based teaching to provide educated and skilled students to the society.

\section{Teachers}

310 full-time teachers in a Yuxi secondary vocational school

\section{Teacher's age}

$<25,25-45$ and $>45$ years old

\section{Gender}

Female and Male

\section{Teaching experience}

$<1$ year, 1 year to 25 years, and $>25$ years

\section{Educational background}

Below bachelor's degree, bachelor's degree, master's degree, and the Doctor.

\section{Reliability Statistics}

\begin{tabular}{ll}
\hline Cronbach's Alpha & N of Items \\
\hline .920 & 22 \\
\hline
\end{tabular}

Part 1 determines the demographic data of teachers in this secondary vocational school.

Part 2 evaluates the current leadership capacity level of teachers in the secondary vocational school. 
Table 5. Collection of data

\begin{tabular}{ll}
\hline Tentative Date & Data Collection Process \\
\hline $20^{\text {th }}$ May 2019 & Request permission from the secondary vocational school \\
$1^{\text {st }}$ and $8^{\text {th }}$ June 2019 & Discussion of objectives and distribution of Survey Questionnaires \\
$22^{\text {nd }}$ June 2019 & Collection of Survey Questionnaires \\
$25^{\text {th }}$ June 2019 & Tabulation and computation of Data \\
\hline
\end{tabular}

Table 6. Summary of the research process

\begin{tabular}{|c|c|c|c|c|}
\hline Research Objectives & Source of Data or Sample & $\begin{array}{l}\text { Data Collection Method } \\
\text { or Research Instrument }\end{array}$ & Data Analysis & $\begin{array}{l}\text { Expected } \\
\text { Results }\end{array}$ \\
\hline $\begin{array}{l}\text { 1. To identify teacher's } \\
\text { age, gender, teaching } \\
\text { experience, educational } \\
\text { background and whether in } \\
\text { an administration position } \\
\text { in a Yuxi secondary } \\
\text { vocational school }\end{array}$ & $\begin{array}{l}310 \text { teachers at a Yuxi } \\
\text { secondary vocational school, } \\
\text { use } 104 \text { as sample }\end{array}$ & $\begin{array}{l}\text { Part I- demographic } \\
\text { profiles of the } \\
\text { responseents: age, } \\
\text { gender, teaching } \\
\text { experience, educational } \\
\text { background. }\end{array}$ & $\begin{array}{l}\text { Frequency } \\
\text { Percentage }\end{array}$ & $\begin{array}{l}\text { The demographic } \\
\text { profiles of teachers at } \\
\text { Yuxi secondary } \\
\text { vocational school }\end{array}$ \\
\hline $\begin{array}{l}\text { 2. To identify the teacher } \\
\text { leadership capacity of } \\
\text { teachers in a Yuxi } \\
\text { secondary vocational } \\
\text { school, Yunnan } \\
\text { Province, China. }\end{array}$ & & $\begin{array}{l}\text { Part II - teacher } \\
\text { leadership capacity }\end{array}$ & $\begin{array}{l}\text { Frequency } \\
\text { Percentage } \\
\text { Mean } \\
\text { Standard } \\
\text { Deviation }\end{array}$ & $\begin{array}{l}\text { The teacher } \\
\text { leadership capacity in } \\
\text { Yuxi secondary } \\
\text { vocational school, } \\
\text { Yunnan } \\
\text { Province, China. }\end{array}$ \\
\hline
\end{tabular}

\section{Data Analysis and Discussion}

\subsection{Data Analysis}

1) Frequency and Percentage: to identify the demographic profiles of the teachers that include teacher's age, gender, schoolwork experience, educational background, whether in an administration position in a Yuxi secondary vocational school.

The survey included 104 teachers, 49 males $(47.1 \%)$ and 55 females $(52.9 \%)$. There are $3(2.9 \%)$ teachers under 25 years old, $54(51.9 \%)$ teachers between 26-35 years old, $27(26.0 \%)$ and 20 teachers between 36-45\% $(19.2 \%)$ of the teachers are older than 45 years old. In terms of school work experience, 3 (2.9\%) teachers have less one-year experience, $21(20.2 \%)$ teachers have 1 to 5 years experience; $43(41.3 \%)$ teachers have $6-15$ years of experience; $18(17.3 \%)$ teachers have 16-25 years of experience, while $19(18.3 \%)$ teachers have more than 25 years of experience. Among these teachers, 17 (16.3\%) hold administrative positions, while $87(2.9 \%)$ have no administrative positions (see Table 1).

Table 7. Frequency and percentage of the demographic profiles of the teachers $(n=104)$

\begin{tabular}{llllll}
\hline & $\mathrm{N}$ & Minimum & Maximum & Mean & Std. Deviation \\
\hline Gender & 104 & 1 & 2 & 1.53 & .502 \\
Age & 104 & 1 & 4 & 2.62 & .828 \\
Educational background & 104 & 1 & 4 & 3.12 & .527 \\
School work experience & 104 & 1 & 5 & 3.28 & 1.074 \\
Whether in an administration position & 104 & 1 & 2 & 1.84 & .372 \\
\hline
\end{tabular}

2) Frequency, Percentage, Mean, and Standard Deviation: to identify the leadership capacity of teachers in the secondary vocational school.

The questionnaire used the five likert point scale (see the Appendix A). Teacher leadership capacity includes four major parts-focus on the vision, reflection, and innovation, shared governance in school and monitors and responses to student achievement. Figures 1 to Figure 4 are the frequency and percentage of these four constructs. As for the intense focus on the vision, 3 people (the minimal number of people) get 5 points, and 18 people (the maximal number of people) get 4 points. From Table 2, reflection and innovation, 3 people (the minimal number of people) get 1.5 points, and the maximum 25 people (the maximal number of people) get 3 points. Table 3 shows 3 people (the minimal number of people) get 1.5 points, and 30 people (the maximal number of people) 
get 3 points. In the last part of monitors and responses to student achievement, 2 people (the minimal number of people) get one points and 24 people (the maximal number of people)obtain 3 points. All the figures exhibit a normal distribution, which means that the medium points share the highest population.

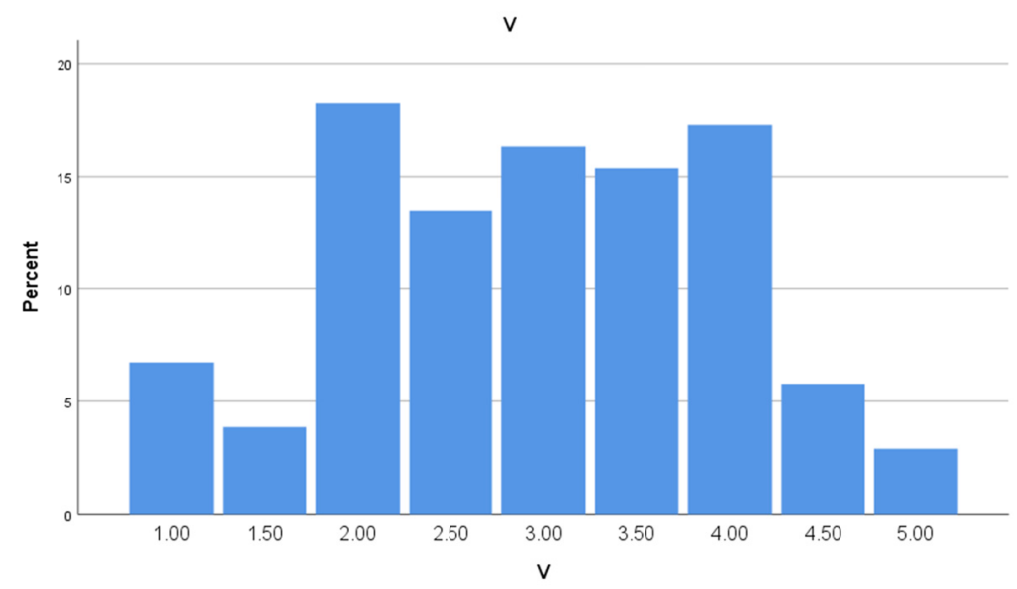

Figure 1. Frequency, percentage of Intense Focus on the vision ( $V=$ Intense Focus on the vision)

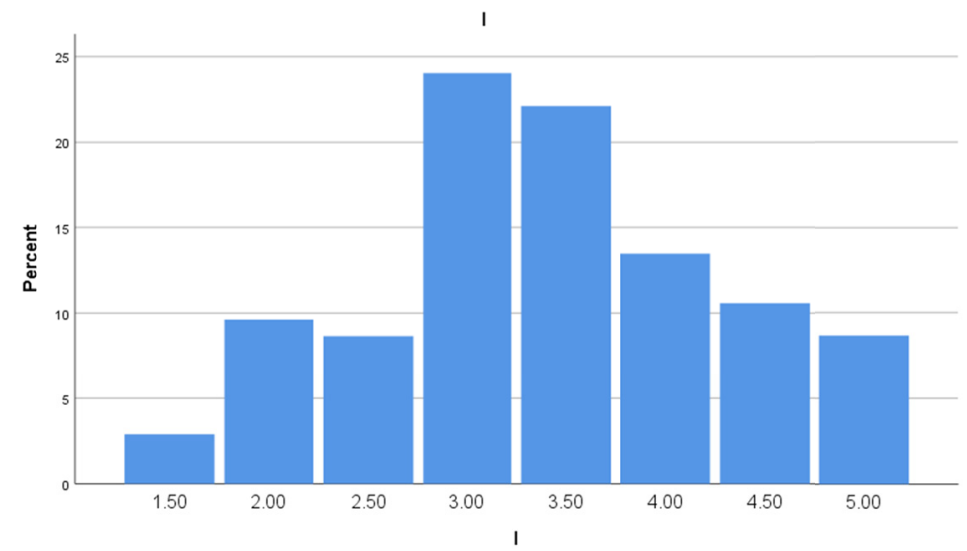

Figure 2. Frequency, percentage of Reflection and Innovation $(I=$ Reflection and Innovation $)$

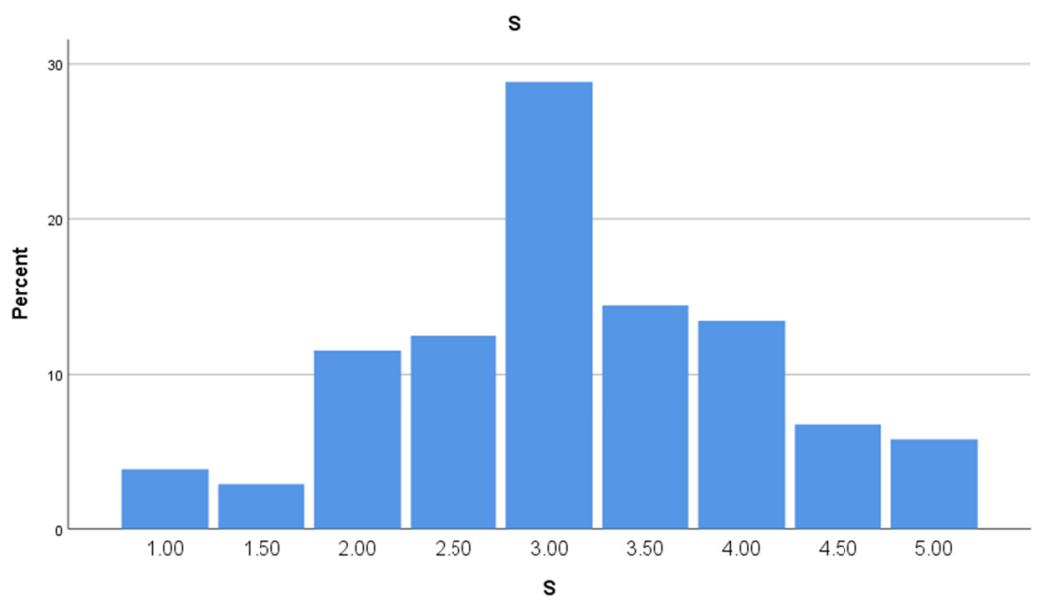

Figure 3. Frequency, percentage of Shared Governance in school ( $I=$ Shared Governance in School) 


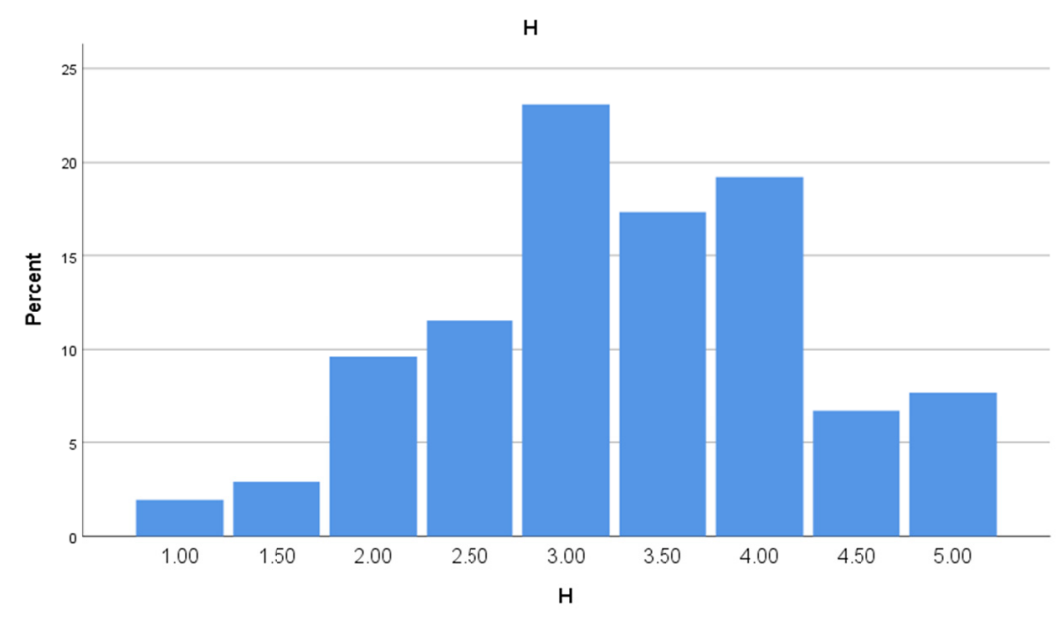

Figure 4. Frequency, percentage of Monitors, and responses to student achievement ( $H=$ Monitors and responses to Student Achievement)

Teacher leadership capacity refers to focus on the vision (V1 to V6), reflection and innovation (I1 to I4), shared governance in school (S1 to S3), monitors, and responses to student achievement (H1 to H4). Table 2 shows the details of the four constructs of teacher leadership capacity. In the "focus on the vision" part, the meaning of "Develop school vision together" and "Have developed new ways to work together" are below 3 points while others are all above 3 points. The SD (=1.302) of "Develop school vision together" is the highest, and the lowest $\mathrm{SD}(=.959)$ is "Have established representative governance groups." The standard deviation of other items is near 1.0 to 1.2 .

Table 8. Mean and standard deviation of the leadership capacity of teachers $(n=104)$

\begin{tabular}{llllll}
\hline & $\mathrm{N}$ & Minimum & Maximum & Mean & Std. Deviation \\
\hline V1 & 104 & 1 & 5 & 2.62 & 1.302 \\
V2 & 104 & 1 & 5 & 3.10 & 1.102 \\
V3 & 104 & 1 & 5 & 3.34 & 1.111 \\
V4 & 104 & 1 & 5 & 3.08 & 1.058 \\
V5 & 104 & 1 & 5 & 3.88 & 1.138 \\
V6 & 104 & 1 & 5 & 3.29 & 1.058 \\
I1 & 104 & 1 & 5 & 3.29 & 1.030 \\
I2 & 104 & 1 & 5 & 3.17 & 1.038 \\
I3 & 104 & 1 & 5 & 2.77 & 1.117 \\
I4 & 104 & 1 & 5 & 3.50 & 1.014 \\
S1 & 104 & 1 & 5 & 3.20 & .959 \\
S2 & 104 & 1 & 5 & 3.03 & 1.186 \\
S3 & 104 & 1 & 5 & 3.05 & 1.194 \\
H1 & 104 & 1 & 5 & 3.15 & 1.086 \\
H2 & 104 & 1 & 5 & 3.44 & 1.003 \\
H3 & 104 & 1 & 5 & 3.25 & 1.068 \\
H4 & 104 & 1 & 5 & 3.44 & 1.050 \\
Valid N (listwise) & 104 & & & & \\
\hline
\end{tabular}

\subsection{Discussion}

There are 3 teachers below 25 years old and 54 teachers (51.9\%) between the ages of $26-35$. The overall average scores of the 17 projects in four levels related to teacher leadership show relatively average levels, which is not very high. This may indicate that the concept of leadership may not be available for the Chinese teachers in this study. There are fewer empirical research schools in China (Hu \& Gu, 2012). All 17 items do not exceed 4.00 points. There is no relationship between teacher leadership and educational background (Angelle \& DeHart, 2011). The length of a teacher's teaching experience may not affect the teacher's leadership. Teaching experience is not important for enhancing teachers' leadership commitment and involving them in 
decision-making (Emira, 2010). Gender is not an important factor affecting educational leadership. When becoming a teacher leader, men and women have almost similar leadership styles (Wittmer, 2001).

The highest and lowest refer to the "focus on vision" section. Participants scored the highest on the "Student Learning Focus" $(\mathrm{M}=3.88)$, the lowest score on the "Co-development School Vision" $(\mathrm{M}=2.62)$ and "have developed new ways of cooperation" $(M=2.77)$. High scores may indicate teachers' beliefs and their views on leadership. Since the core function of the school is teaching and learning, almost all teachers on the campus are taking care of students' learning. Two projects mentioned "together", which may reflect the schools' lack of a collaborative culture. The SD (=1.302) of the "Co-development School Vision" is the highest, which means that the project is more unstable. In addition, the mean is the lowest $(\mathrm{M}=2.62)$. In terms of "co-development of school vision", teachers may show more differences. Few of them are good at this, and many of them need to develop. He and Rao (2015) believed that vision is very important for teacher development. In addition, the lowest $\mathrm{SD}(=.959)$ is "a representative governance group has been established".

\section{Implication}

\subsection{The Strategies to Develop Teacher Leadership Capacities}

Lambert (1998) believed that leadership is a kind of relationship learning, which can promote the members of the organization to create value for common goals. The leadership capabilities established by the principal include informing participants about new leadership capabilities. Other strategies enhance teacher leadership:

1) Hiring experts for leadership work to help senior employees grow into leaders;

2) Let everyone know each other and build trust;

3) Assess the leadership abilities of teachers and schools. For example, do we have a common vision? Do we cooperate? Do we care about students' learning and development?

4) Establish a culture of inquiry that encourages people to think, ask questions, gather evidence, and plan improvements;

5) Manage leadership by establishing inclusive governance.

\subsection{Develop School Vision for Teachers}

How to form a common vision? Regarding this issue, Lambert (2000) reported that the principal of the school would usually propose a vision and then try to sell it on campus, which is a traditional way. Leaders embed the vision into the hope and passion of everyone in the organization. However, Lambert and her colleagues published a book (2002) that described the school principals in shared leadership, developing common goals, and sharing responsibility for difficult issues. Educational leaders should focus, ask questions curiously and bravely, and pay attention to teaching and learning.

Supervisors must involve every educational organization and develop a vision and mission statement to explain the purpose and reason for taking concerted action. This process is created through the inclusiveness and collaboration of each school. The principal is mainly involved in "management vision, mission and common goals". The purpose of school education is to reverse all aspects of a comprehensive educational institution, which is the responsibility for the new educational task. Knowledge is beneficial experience for both students and teachers, and it is the basis for reforming big issues, dialogue and learning. The purpose is similar to vision, while it occurs in the dialogue. Through the process of constructing leadership, there may be an inspiration of rethinking the goal of the teachers.

\subsection{Establish Collaboration Culture and Atmosphere Among Teachers}

School leaders must involve teachers in the dialogue, professional learning, and reflection, which are important strategies for enhancing teacher leadership and development (Lambert et al., 2002). The active collaborative practice is as follows:

- Make each participant an effective contributor;

- Treat teachers as experts;

- Create a platform for sharing, conversation and comment;

- Give learning ownership to participants;

- Learn in practice and provide various practical points to professional groups,

- Share leadership; 
- Rethink professional identity and connect it to the professional learning community (Lambert, 2003b)

\subsection{Significance of the Study}

Therefore, the teacher leadership capacity of the secondary vocational school in Yuxi is determined in this investigation. It will introduce the knowledge and opinions of teachers' leadership in this secondary vocational school. Reference will be made to the knowledge of leadership teacher development in this school. School leaders and administrators can understand teachers' views on leadership. Teacher leadership becomes part of the school reform and hence the investigation is necessary. There are new models and opportunities to develop teacher leadership, and teachers want more opportunities to lead and visit leaders at certain levels. Education managers can provide support for teachers with formal leadership positions. Future researchers will gain background knowledge and information about teachers' leadership in secondary vocational education in China. Future research can be further carried out on teacher leadership in other secondary vocational schools in China.

\section{Conclusion}

With the improvement of teacher leadership status, it is very important to check and determine the level of teacher leadership in the school. For vocational high schools, teachers have a certain level of leadership, which is beneficial to the construction and development of the schools. This paper used a questionnaire survey to explore the current situation of teacher leadership in an intermediate vocational college in Yuxi City, Yunnan Province, China. The data analysis results show that the teacher's leadership level needs to be improved, and the background information of teachers does not produce any leadership influences. Combining the literature review and analysis results, the authors of this article proposed feasible and effective strategies for promoting the leadership capacities of vocational school teachers.

\section{Acknowledgment}

The authors acknowledge the financial support through General Program of China Postdoctoral Science Foundation: "Comparative Study on Governance Model between National Southwest Associated University and National Northwest Associated University".

\section{(2017M610787).}

\section{References}

Anderson, T. J., Barrick, R. K., \& Hughes, M. (1992). Responsibilities of Teacher Education for Vocational Teacher Professional Development Programs. Journal of Agricultural Education, 33(2), 43-50. https://doi.org/10.5032/jae.1992.02043

Angelle, P. S., \& DeHart, C. A. (2011). Teacher Perceptions of Teacher Leadership: Examining Differences by Experience, Degree, and Position. NASSP Bulletin, 95(2) 141-160. https://doi.org/10.1177/0192636511415397

Attwell, G. (1997). New roles for vocational education and training teachers and trainers in Europe: A new framework for their education. Journal of European Industrial Training, 21(6/7), 256-265. https://doi.org/10.1108/03090599710171558

Bakar, R. (2018). The influence of professional teachers on Padang secondary secondary vocational school students' achievement. Kasetsart Journal of Social Sciences, 39(1), 67-72. https://doi.org/10.1016/j.kjss.2017.12.017

Beek, V. J. A., Jong, F. P. C. M., Minnaert, A. E. M. G., \& Wubbels, T. (2014). Teacher practice in secondary vocational education: Between teacher-regulated activities of student learning and student self-regulation. Teaching and Teacher Education, 40, 1-9. https://doi.org/10.1016/j.tate.2014.01.005

Billett, S. (2011). Vocational Education: Purposes, Traditions and Prospects. Berlin: Springer. https://doi.org/10.1007/978-94-007-1954-5

Bruijin, E., Billet, S., \& Onstenk, J. (2017). Enhancing teaching and learning in the Dutch vocational education system. Berlin: Springer. https://doi.org/10.1007/978-3-319-50734-7

Brundrett, M., Burton, N., \& Smith, R. (2003). Leadership in education. California: Sage publication.

Bunning, F. (Ed.). (2006). The Transformation of VET in the Baltic States (pp. 113-137). Springer. Printed in the Netherlands.

Bush, T. (2007). Educational leadership and management: Theory, policy, and practice. South African Journal of Education, 27(3), 391-406. 
Claus, J. F. (1989). Renegotiating vocational instruction. The Urban Review, 21(4). https://doi.org/10.1007/BF01112402

Constant, L., Culbertson, S., Stasz, C., \& Vernez, G. (2014). Improving Technical Vocational Education and Training in the Kurdistan Region -Iraq. California: RAND Corporation. https://doi.org/10.7249/RR277

Dan, S. G. D. (2014). A study of effects on teacher leadership in higher education-based on survey of one university in Yunnan province. Education and Learning Journal, 13.

Day, C., \& Sammons, P. (2015). Successful school leadership. Education Development Trust. Retrieved from http://www.educationdevelopmenttrust.com

Drummer, J., Hakimov, G., Joldoshov, M., \& Kohler, T. (2018). Vocational Teacher Education in Central Asia Developing Skills and Facilitating Success. Berlin: Springer. https://doi.org/10.1007/978-3-319-73093-6

Emira, M. (2010). Leading to Decide or Deciding to Lead? Understanding the Relationship Between Teacher Leadership and Decision Making. Educational Management Administration \& Leadership, 38(5), 591-612. https://doi.org/10.1177/1741143210373738

English, F. W., Papa, R., Mullen, C. A., \& Creighton, T. (2012). Educational leadership at 2050: Conjectures, Challenges, and practices. Lanham: Roman \& Littlefield Publishers, INC.

Grant, C. C. (2017). Excavating the South African teacher leadership archive: Surfacing the absences and reimagining the future. Educational Management Administration \& Leadership, 1-19. https://doi.org/10.1177/1741143217717274

Grollmann, P. (2008). The Quality of Vocational Teachers: Teacher education, institutional roles and professional reality. European Educational Research Journal, $7(4)$. https://doi.org/10.2304/eerj.2008.7.4.535

Hallinger, P. (2013). A conceptual framework for systematic reviews of research in educational leadership and management. Journal of Educational Administration, 51(2), 126-149. https://doi.org/10.1108/09578231311304670

Hamilton, G., Forde, C., \& McMahon, M. (2018). Developing a coherent strategy to build leadership capacity in Scottish education. Management in Education, 32(2), 72-78.

He, J. W., \& Rao, C. M. (2015). Vision: An important representation of teacher development. Teacher Education Research, 27(3).

Hodkinson, P. (1998). Technicism, teachers and teaching quality in vocational education and training. Journal of Vocational Education \& Training, 50(2), 193-208. https://doi.org/10.1080/13636829800200045

Hu, J. F., \& Gu, L. X. (2012). A survey of the situation of teacher leadership and impact factors in China. Curriculum, Teaching Material and Method, 32(5).

Jiandong, S. (2018). Vocational teacher leadership: Content, value, and development. Jiangsu Higher Education.

Lambert, L. (1998). How to build leadership capacity. Educational Leadership, 55(7), 17.

Lambert, L. (2003a). Leadership Capacity for Lasting School Improvement. Alexandria, VA: ASCD.

Lambert, L. (2003b). Leadership Redefined: An evocative context for teacher leadership. School Leadership \& Management, 23(4), 421-430. https://doi.org/10.1080/1363243032000150953

Lambert, L., Walker, D., Zimmerman, D. P., Copper, J. E., Lambert, M. D., Gardner, M. D., \& Szabo, M. (2002). The Constructivist Leader (2nd ed.). New York: Teachers College Press.

Leithwood, K. A., \& Hallinger, P. (2002). Second international handbook of educational leadership and administration. Berlin: Springer. https://doi.org/10.1007/978-94-010-0375-9

Leithwood, K. A., \& Riehi, C. (2003). What we know about successful leadership. Philadelphia, PA: Laboratory for student success, Temple University.

Li, K. Y., Hau, C. S., Huang, Y. C., \& Huang, D. F. (2011). A Study of the Influence of Creative Thinking Instruction Implemented in the Engineering Education "Mold Production Practice" Curriculum on the Creativity of Vocational High School Students. Springer-Verlag Berlin Heidelberg. https://doi.org/10.1007/978-3-642-24022-5_40

Lin, S. (2008). Development and transformation of vocational education in China. Chinese Vocational and Technical Education, Nov. 21. 
Lin, S., \& Ting, X. G. (2015). China secondary vocational education reform and transformation: analysis based on education policy. Chinese Vocational and Technical Education, 33.

Marion, R., \& Gonzales, L. D. (2014). Leadership in education: Organizational theory for the practitioner (2nd ed.). Illinois: Waveland press, Inc.

Martins, D., Carvalho, C., \& Pacheco, J. (2015). Curriculum differentiation: A study with institutionalized young's attending vocational education. Procedia - Social and Behavioral Sciences, 174, 2590-2595. https://doi.org/10.1016/j.sbspro.2015.01.937

Ming, Z. Y. (2008). The thoughts of $K-12$ teacher leadership research in foreign countries. Comparative educational review.

Mouzakitis, G. S. (2010). The role of vocational education and training curricula in economic development. Procedia Social and Behavioral Sciences, 2, 3914-3920. https://doi.org/10.1016/j.sbspro.2010.03.616

OECD. (2006). The Program for International Student Assessment. Retrieved from https://www.oecd.org/pisa/pisaproducts/39725224.pdf

OECD. (2011). Reviews of vocational education and training.

Oser, F., Salzmann, P., \& Heinzer, S. (2009). Measuring the competence-quality of vocational teachers: An advocatory approach. Empirical Research in Vocational Education and Training, 1, 65-83. https://doi.org/10.1007/BF03546480

Seezink, A. F., \& Poell, F. R. (2010). Continuing professional development needs of teachers in schools for competence-based vocational education: A case study from The Netherlands. Journal of European Industrial Training, 34(5), 455-474. https://doi.org/10.1108/03090591011049819

Shidong, L. (2011). Research on Macro Instructional Design of Electronic Technology Course for Different Major Vocational Students. Springer-Verlag Berlin Heidelberg. https://doi.org/10.1007/978-3-642-24022-5_48

Sigurðardottir, S. M., \& Sigporsson, R. (2016). The fusion of school improvement and leadership capacity in an elementary school. Educational Management Administration \& Leadership, 44(4), 599-616. https://doi.org/10.1177/1741143214559230

Silva, D. Y., Gimbert, B., \& Nolan, J. (2000). Sliding the Doors: locking and unlocking possibilities of teacher leadership. Teacher College Record, 102(4), 779-804. https://doi.org/10.1111/0161-4681.00077

Smylie, M. A., \& Eckert, J. (2017). Beyond superheroes and advocacy: The pathway of teacher leadership development. Educational Management Administration \& Leadership, 46(4), 556-577. https://doi.org/10.1177/1741143217694893

Vähäsantanen, K. (2013). Vocational Teachers' Professional Agency in the Stream of Change. JYVÄSKYLÄ Studies in education, psychology and social research.

Wenner, J. A., \& Campbell, T. (2017). The Theoretical and Empirical Basis of Teacher Leadership: A Review of the Literature. Review of Educational Research, 87(1), 134-171. https://doi.org/10.3102/0034654316653478

Wittmer, C. R. (2001). Leadership and Gender-Role Congruency: A Guide for Wilderness and Outdoor Practitioners. The Journal of Experiential Education, 24(3), 173-178. https://doi.org/10.1177/105382590102400308

Wrigle, T. (2002). Review of the book The Leaders and leadership in education. Improving Schools, 5(3). https://doi.org/10.1177/136548020200500317

\section{Appendix A}

\section{Questionnaire}

Part I. General Information: please tick $(\checkmark)$ the following information in the space provided.

1. Age

$$
\begin{aligned}
& \text { () }<25 \\
& \text { ( ) } 25-35
\end{aligned}
$$



( ) $36-45$
( ) $>45$

2. Gender
( ) Male
( ) Female

3. School work experience

$$
\begin{aligned}
& \text { ( ) }<1 \text { year } \\
& \text { ( ) } 1 \text { year }-5 \text { years } \\
& \text { ( ) } 6 \text { years }-15 \text { years } \\
& \text { ( ) } 16 \text { years }-25 \text { years } \\
& \text { ( ) }>25 \text { years }
\end{aligned}
$$

4. Educational background
( ) Below Bachelor degree
( ) Bachelor degree
( ) Master degree
( ) Doctor degree

5. Are you in an administration position?
() Yes
() Not

Part II. Teacher Leadership Capacity Questionnaire

The 1-5 scale represents the followings:

$1=$ we do not do this at our school

$2=$ we are starting to move in this situation

$3=$ we are making good progress here

$4=$ we have this condition well established

$5=$ we are refining our practice in this area 
Please tick $(\boldsymbol{V})$ your answer to the following statements:

\begin{tabular}{|c|c|c|c|c|c|c|}
\hline Item NO. & Construct 1: Intense focus on the vision. In our school, we: & $\begin{array}{l}\text { The greatest } \\
\text { need }\end{array}$ & need & $\begin{array}{l}\text { Good } \\
\text { enough }\end{array}$ & strength & $\begin{array}{l}\text { Represent } \\
\text { exemplary }\end{array}$ \\
\hline 1 & Develop school vision together & 1 & 2 & 3 & 4 & 5 \\
\hline 2 & $\begin{array}{l}\text { Ask everyone questions that keep us on track with our } \\
\text { vision }\end{array}$ & 1 & 2 & 3 & 4 & 5 \\
\hline 3 & $\begin{array}{l}\text { Think jointly about how to align our standards, instruction, } \\
\text { assessment, And programs with our vision }\end{array}$ & 1 & 2 & 3 & 4 & 5 \\
\hline 4 & Keep our vision alive by reviewing it regularly & 1 & 2 & 3 & 4 & 5 \\
\hline 5 & Focus on student learning & 1 & 2 & 3 & 4 & 5 \\
\hline \multirow[t]{2}{*}{6} & $\begin{array}{l}\text { Use data/evidence to inform our decisions and teaching } \\
\text { practices }\end{array}$ & 1 & 2 & 3 & 4 & 5 \\
\hline & Construct 2: reflection and innovation & 1 & 2 & 3 & 4 & 5 \\
\hline 7 & $\begin{array}{l}\text { Make time for ongoing reflection (e.g., journaling, peer } \\
\text { coaching, collaborative planning) }\end{array}$ & 1 & 2 & 3 & 4 & 5 \\
\hline 8 & $\begin{array}{l}\text { Encourage individual and group initiative by providing } \\
\text { access to resources, personnel, and time. }\end{array}$ & 1 & 2 & 3 & 4 & 5 \\
\hline 9 & $\begin{array}{l}\text { Have joined with networks of other schools and programs, } \\
\text { both inside and outside the district, to secure feedback on } \\
\text { our work. }\end{array}$ & 1 & 2 & 3 & 4 & 5 \\
\hline 10 & Practice and support new ways of doing things & 1 & 2 & 3 & 4 & 5 \\
\hline 11 & $\begin{array}{l}\text { Develop our own criteria for accountability regarding } \\
\text { individual and shared work } \\
\text { Construct 3: shared governance in our school, we: }\end{array}$ & 1 & 2 & 3 & 4 & 5 \\
\hline 12 & Have established representative governance groups & 1 & 2 & 3 & 4 & 5 \\
\hline 13 & Seek to perform outside of traditional roles & 1 & 2 & 3 & 4 & 5 \\
\hline 14 & $\begin{array}{l}\text { Have developed new ways to work together } \\
\text { Construct 4: Monitors and responses to student achievement } \\
\text { In our school, we: }\end{array}$ & 1 & 2 & 3 & 4 & 5 \\
\hline 15 & Teach and assess so that all children learn & 1 & 2 & 3 & 4 & 5 \\
\hline 16 & $\begin{array}{l}\text { Provide feedback to children and families about student } \\
\text { progress }\end{array}$ & 1 & 2 & 3 & 4 & 5 \\
\hline 17 & $\begin{array}{l}\text { Talk with families about student performance and school } \\
\text { programs }\end{array}$ & 1 & 2 & 3 & 4 & 5 \\
\hline
\end{tabular}

\section{Copyrights}

Copyright for this article is retained by the author, with first publication rights granted to the journal.

This is an open-access article distributed under the terms and conditions of the Creative Commons Attribution license (http://creativecommons.org/licenses/by/4.0/). 